UDC 631.1

DOI: https://doi.org/10.32782/2415-8801/2020-6.19

\author{
Tkachenko Victoriia \\ PhD of Economics, Associate Professor, \\ Associate Professor of Management Department, \\ Sumy National Agrarian University
}

\title{
DISADVANTAGES AND WAYS OF IMPROVING THE ECONOMIC MECHANISM OF ENVIRONMENTAL MANAGEMENT
}

The essence of the concept "reconomic mechanism of use of natural resources" is considered, its tasks, principles and structure are generalized, features of its elements are considered. The domestic experience of application of the economic mechanism for stimulation of effective use of natural resources in Ukraine is studied. The role and influence of the economic mechanism on the management of natural resources use is studied and analyzed, the problems of ecologically oriented development of agro-industrial complex management, introduction of ecological taxes and increase of fines for violation of nature protection legislation at the local level are investigated. The necessity of finding modern ways of developing and improving an effective economic mechanism of nature management is substantiated. It is determined that the main purpose of the economic mechanism of nature management is the rational use of natural resources. Ways to improve the economic mechanism of nature management in Ukraine have been identified. It is established that the task of tax policy in the use of natural resources by agricultural enterprises is to reduce the tax burden on them, simplify tax accounting and increase its transparency and reliability, creating favorable conditions for agricultural producers.

Keywords: economic mechanism of natural resources use, natural resources, environmental activities, natural resources management.

\section{НЕДОЛІКИ ТА ШЛЯХИ УДОСКОНАЛЕННЯ ЕКОНОМІЧНОГО МЕХАНІЗМУ УПРАВЛІННЯ ПРИРОДОКОРИСТУВАННЯМ}

Ткаченко Вікторія

Сумський національний аграрний університет

У статті розглянуто сутність поняття «економічний механізм використання природних ресурсів», узагальнено його завдання, принципи та структуру, розглянуто особливості його елементів. Дано вітчизняний досвід застосування економічного механізму для стимулювання ефективного використання природних ресурсів в Украӥні. Досліджено та проаналізовано роль та вплив економічного механізму на управління процесом використання природних ресурсів, досліджено проблеми еколого-орієнтованого розвитку землегосподарювання АПК, впровадження екологічних податків та збільшення иттрафів за порушення природоохоронного законодавства намісцевому рівні. Обгрунтовано важлива роль у системі економічних інструментів використання природних ресурсів сільськогосподарськими підприємствами відіграє податкова політика, яка передбачає стягнення платежів за право користування природними ресурсами. Встановлено, що завданням податкової політики в сфері використання природних ресурсів сільськогосподарськими підприємствами є зниження податкового тиску на них, спрощення податкового обліку та підвищення його прозорості й достовірності, створення сприятливих умов для аграрних товаровиробників. 3 метою удосконалення економічного механізму y сфері природокористування, запропоновано скоротити перелік икідливих речовин, за які стягуються платежі й підвищити нормативну плату за скиди найшкідливіших з них; закласти в основу розрахунків плати за забруднення залежність між розміром плати й величиною загальних витрат сільськогосподарських 
підприємств та ін. Доведено доцільність удосконалення системи итрафних санкцій при порушенні умов використання природних ресурсів підприємствами. Запропоновано стратегію фінансування природоохоронних заходів шляхом формування цільових фондів. Обгрунтовано необхіність пошуку сучасних шляхів розроблення та вдосконалення ефективного економічного механізму природокористування. Визначено, ццо основною метою економічного механізму природокористування с раціональне використання природних ресурсів. Встановлено иляхи удосконалення економічного механізму природокористування в Україні.

Ключові слова: економічний механізм використання природних ресурсів, природні ресурси, природоохоронна діяльність, управління природними ресурсами.

Formulation of the problem. One of the biggest acute and complex problems today is the rational use, reproduction and protection of natural resources from pollution, degradation and depletion.

In the process of socio-economic development of the country, there is a need to find new quality approaches to solving problems of environmental protection and rational use of natural resources by agricultural enterprises, greening of production, increase of soil fertility, reduction of pollution of water and air resources, preservation and restoration of forest resources.

Analysis of recent research and publications. The problem of finding ways to improve the economic mechanism of nature management has long been an object of economic research but still not fully disclosed. The works of L. Abalkin, A. Aksenenko, O. Veklich, O. Gavrilenko, B. Burkinsky, B. Danylyshyn, V. Golyan [6], R. Dubas [1], J. Koval, V. Mishchenko, L. Melnyk [4], V. Stepanova, N. Stepaniuk, M. Khvesyk and others are devoted to the problems of rational use of natural resources.

The purpose of the article. The aim of the article is to determine the need and improve the economic mechanism as an effective tool for rational management of the process of using natural resources.

Presentation of the main results. Reforming economic relations in the agricultural sector is impossible without the reproduction of natural resources, which requires the improvement of regulatory and legal support, economic tools and methods, information support to increase the efficiency of agricultural production, taking into account environmental aspects.

The development of social relations and the improvement of tools have led to more intensive use of natural resources, especially in agriculture. Satisfaction of human needs requires the involvement of increasing amounts of natural resources in the production process, accompanied by irrational and exhausting use, increased emissions of pollutants into the environment, which has a negative impact on human life and health.

The use of natural resources in agricultural production is characterized by the development of productive forces, increasing their use, especially land, and the rate of environmental pollution, deteriorating health of the working population, reduced productivity.

Socio-economic growth is due to the following:

- increasing the involvement of natural resources in agricultural production without changing the efficiency of their use;

- increasing the involvement of natural resources in agricultural production with increasing the efficiency of their use;

- increasing the efficiency of natural resources in agricultural production without increasing their volumes.

A promising direction of economic growth is the thirdintensive growth.
It should be noted that the full transition to the intensive direction of development requires significant changes in the economic mechanism of use of natural resources by agricultural enterprises, the introduction of progressive relations on a competitive basis, with due regard for nature.

Irrational use of natural resources, especially in agriculture, «leads to their depletion; deterioration of quality characteristics as a result of operation. There is a decrease in land fertility, degradation and destruction of forests, disruption of water systems and their pollution, relief transformation» [1, p. 50].

Non-compliance of economic development with the requirements of environmental security, priority of natureintensive industries, high share of resource- and energyintensive obsolete technologies in agriculture, raw material export orientation, as well as low level of ecological culture and consumption lead to deepening economic crises, environmental degradation.

«The modern type of ecological and economic development is defined as man-made, based on the use of artificial means of agricultural production, created without taking into account economic constraints» [1, p. 135]. «The technocratic concept of national agriculture, which is based on the quantitative increase of technical, agrochemical factors of intensification of agricultural production, the use of industrial technologies and their maximum involvement in the use of natural resources, did not provide adequate efficiency. This concept has caused excessive negative anthropogenic pressures on nature, undermined its restorative and self-regulating capabilities of the latter» [2, p. 7]. In this case, «economic damage is inflicted, which is a cost estimate of the degradation of natural resources and environmental pollution under the influence of anthropogenic factors. This type of development is aimed at combating the negative environmental consequences of economic development, rather than the causes of their occurrence» $[3$, p. 41].

One of the ways to overcome the ecological and economic crisis is to build such economic relations in society that would contribute to changes in the structure of agricultural production through the introduction of resource-saving, low-waste, environmentally friendly technologies and modernization of agricultural machinery.

Positive changes in the economy can be achieved through the introduction of effective policies for the further development of agriculture and agricultural enterprises in general. The means of implementing such a policy include investment activities, a system of economic incentives from the state (preferential taxation, lending, subsidies), improving the legal framework.

The economic mechanism of use of natural resources by agricultural enterprises is an effective way to regulate resource use in the agricultural sector, the development of which is to compensate for losses in man-made natural 
disasters, their assessment; damage prevention; ensuring legal and economic protection of production activities; increasing responsibility for increasing risk.

According to Melnyk L., «economic mechanism - is a set of economic structures, institutions, forms and methods of management, through which the current economic laws are implemented in specific conditions and the coordination and adjustment of public, group and private interests» [4, p. 458].

Tarkhov P. under the economic mechanism of natural resources use means a set of forms and methods of regulation (regulation) of agricultural production through the simultaneous use of market-oriented administrative, economic and social management methods [5, p. 78].

Golyan V. considers the economic mechanism of natural resources use as «a set of forms, methods and ways to regulate the use of natural resources and environmental protection» [6, p. 6]. Dubas R. believes that the economic mechanism of natural resources use by agricultural enterprises is a set of interconnected methods and levers, «focused on the rationalization of natural resources and environmental protection while expanding their use or focus on stabilizing and reducing the scale of use natural resources» [1, p. 363].

We believe that the economic mechanism of use of natural resources by agricultural enterprises is a system of interconnected tools and levers aimed at establishing the efficient use of natural resources, taking into account their optimal use and reproduction.

Currently, the following types of economic mechanism for the use of natural resources by agricultural enterprises are distinguished:

- aimed at eliminating the negative environmental consequences, rather than the causes of environmental change, which has little effect on the pace and scale of development of agricultural sectors, almost without restraining their activities;

- stimulating development of ecologically balanced and nature protection enterprises in the agricultural sphere, which promotes the increase of agricultural production on the basis of new technologies, allows to improve the use and protection of natural resources (for example, development of biological agriculture);

- does not promote the development of agricultural enterprises in the direction of expanding their natural base, providing for the economical use of natural resources.
It should be noted that none of the types of economic mechanism for the use of natural resources by agricultural enterprises exists in its pure form.

We propose to identify the following main elements of the economic mechanism of use of natural resources by agricultural enterprises:

- pricing taking into account the environmental factor;

- economic instruments of environmental protection;

- system of financing environmental measures;

- payment for the use of natural resources;

- environmental insurance;

- economic and environmental regulation.

In general, the modern economic mechanism of use of natural resources by agricultural enterprises can be represented by a block diagram shown in Figure 1.

In Ukraine, the concept of «free» natural resources or their minimum price has existed for a long time. It is in the absence of real prices for natural resources and is the main problem of using natural resources, which contributed to their irrational and wasteful use [7, p. 67].

Payments by enterprises to environmental funds do not fully contribute to the rational use of natural resources.

The components of prices for natural resources are prices for raw materials, energy; payments for the right to use land, water, forest and other natural resources; payments for the use of the assimilation potential of ecosystems (for pollution); rent for the use of fixed assets, including environmental purposes.

Most scientists are inclined to believe that real prices of natural resources can be an effective lever in the market mechanism and vice versa, with the irrational use of natural resources in agricultural enterprises, their accounting will lead to a deterioration in production, which will directly affect the financial results.

Any purchase or sale of land involves the pricing of the land, which in turn depends on the fertility of the land and its location. Thus, the price of land does not depend on its value, but on the income that the land brings to its owner during operation, i.e. on rent, which also serves as a chain of combination with the economic assessment of land use [8, p. 23].

An important role in the system of economic instruments for the use of natural resources by agricultural enterprises is played by tax policy, which provides for the collection of payments for the right to use natural resources (for example, for the use of land resources for agricultural

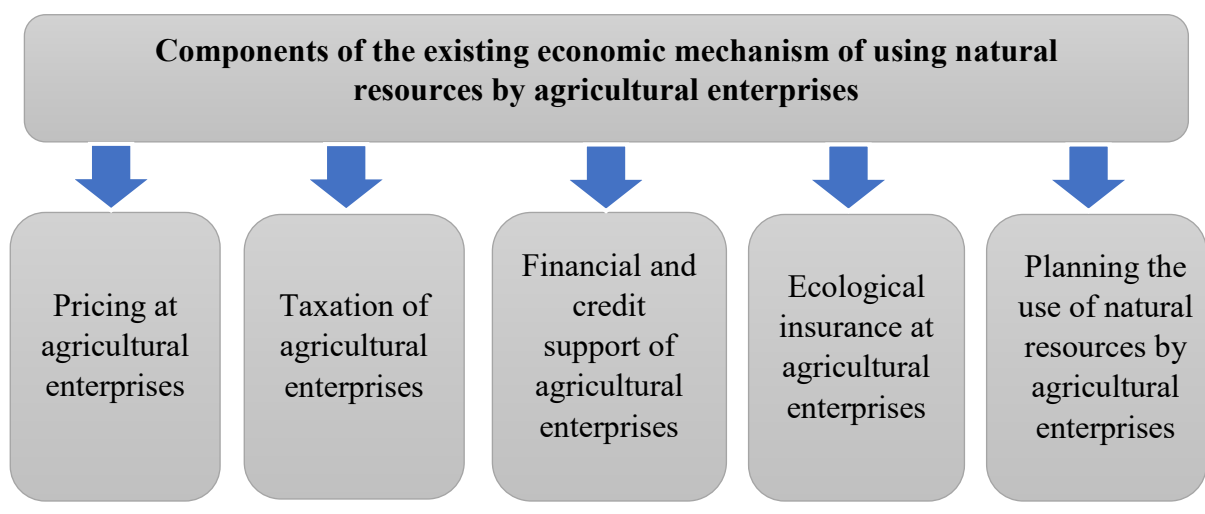

Figure 1. Components of the existing economic mechanism of using natural resources by agricultural enterprises 
enterprises is set in the form of land tax or rent); payments for the reproduction and protection of natural resources; compensation payments for the disposal of natural resources from their intended use or deterioration of their quality (for example, payments for the withdrawal of agricultural land); payments for environmental pollution (for emissions of pollutants from stationary sources and transport, discharges of wastewater into water bodies, waste disposal, etc.).

One of the main taxes paid depending on the availability of land by the payer is the land fee.

Payment for land is a direct tax on the ownership or use of land, which is levied either in the form of land tax or rent. The rent is determined depending on the monetary value1 ha a certain type of land.

Land tax payers include both legal entities and individuals who own land or use it, including on lease terms. That is, the land tax is a combined tax on its classification depending on the subjects of taxation.

The amount of payment for land is actually determined by the area of the land plot and the monetary value 1 ha land and does not depend on the results of production and economic activities of the payer. The calculation of the amount of land tax is based on the total amount of tax for the current year as of January 1 of the following year.

The task of tax policy in the use of natural resources by agricultural enterprises is to reduce the tax burden on them, simplify tax accounting and increase its transparency and reliability, optimize the timing of taxes, create favorable conditions for agricultural producers. Reduction of tax pressure is most often realized through the establishment of tax benefits, which should be provided taking into account the level of environmental measures, greening of production activities. The reduction of the tax rate should be applied to resource-saving and low-waste technologies. At a higher rate it is necessary to tax the activities of agricultural enterprises that use harmful, ozone-depleting drugs, pesticides, energy-intensive equipment and more.

Important are «green» (environmental) taxes, which allow to make the cost of agricultural products more adequate in relation to costs, as well as to help compensate for environmental damage by the polluter, not the whole society (implementation of the «polluter pays» principle).

The modern tax system is aimed at collecting taxes on income, value added, etc. The fee for the use of natural resources is a few percent of the revenue side of the budget, encouraging nature-exploiting activities. In our opinion, it is expedient to change the proportions in favor of increasing the share of taxes related to the use of natural resources, first of all, fees for the right to use resources, «green» taxes. It is advisable to introduce tax incentives in agriculture to encourage the greening of agricultural enterprises (Figure 2).

We believe that the principle of paid use of natural resources should be implemented in the following areas:

- introduction of a fee for the acquisition of natural resources;

- payment for the use of natural resources, for the negative impact, deterioration of its condition.

Measures to improve the economic mechanism for the use of natural resources by agricultural enterprises in the field of taxation should include a reduction in the list of harmful substances for which fees are charged and increase the regulatory fee for discharges of the most harmful of them; to lay in the basis of calculations of the payment for pollution dependence between the size of a payment and size of the general expenses of the agricultural enterprises; not to take into account the amount of payment for environmental pollution in the cost of production; to introduce a procedure for collecting payments for limit and over-limit pollution of the environment directly from the profits of agricultural enterprises; to introduce tax benefits by taking into account in the payments for pollution funds that were sent by the company for the implementation of environmental measures, introduction of resource-saving and low-waste technologies.

Fines, sanctions for the irrational use of natural resources by agricultural enterprises and environmental pollution should be given importance in the system of paid use of natural resources in agriculture. In case of land acquisition

Tax incentives for the ecological direction of agricultural production

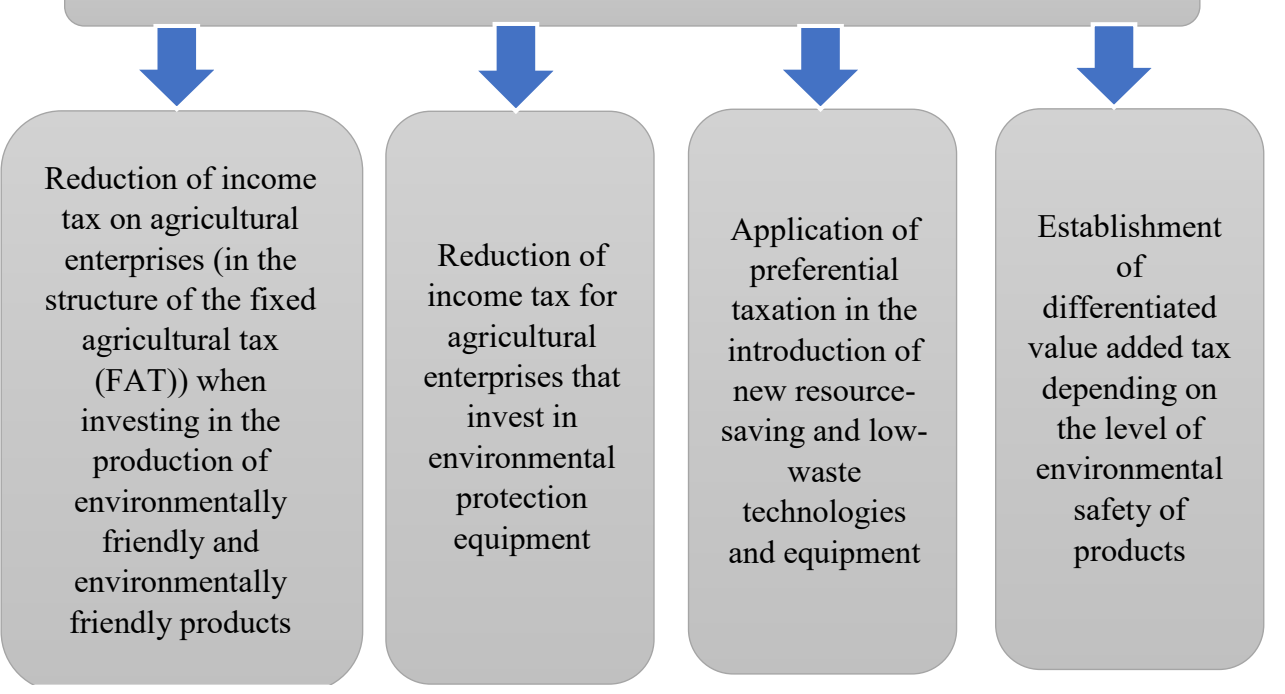

Figure 2. Tax incentives for the ecological direction of agricultural production 
due to its irrational use, air or water pollution in excess of established standards, it is necessary to use economic and legal levers to combat violators. It is advisable to improve the system of penalties for violations of the conditions of use of natural resources by enterprises.

The current economic mechanism does not create prerequisites for full financing of current costs for the rational use of natural resources by agricultural enterprises and their reproduction. The effectiveness of financial support of current costs depends on the completeness and timeliness of payment of fees for environmental pollution, as well as on the financial capacity of agricultural enterprises. At present, economic damage is not fully compensated for economic damage.

Compensation for damage involves compensation for damage to the environment to individual businesses, including the public. In this case, it is not a question of direct compensation of damage directly to the population, but of indirect compensation - by carrying out compensatory measures (construction of hospitals, etc.). The remaining funds should be used for environmental programs of national and regional importance, conservation and reproduction of natural resources, creation of facilities for waste disposal, development of new environmentally friendly technologies, etc. Then the circulation of these funds in the field of agricultural activity will be carried out.

«The system of state subsidies for agriculture needs to be significantly improved. Currently, it does not fully contribute to the rational use of natural resources by agricultural enterprises, because it is aimed at financing producers of inefficient agricultural machinery, subsidizing environmentally friendly projects, global and irrational measures for irrigation and drainage, purchase of fertilizers and pesticides».

The disadvantage of the system of financing environmental measures is that most of the investment comes from the state budget and depends, as a rule, on the economic situation in the country, rather than on the needs of reproduction of natural resources. To improve the situation, we propose to leave public investment in nature protection in the budget (to finance large-scale national and regional programs), and to finance current expenditures to form trust funds based on payments for pollution, fines for violations of environmental legislation.

An important role in the formation of an effective economic mechanism for the use of natural resources by agricultural enterprises belongs to the state, because it establishes the main directions, parameters and procedure for their application, the priority of which is the protection and rational use of natural resources by agricultural enterprises. One of the most important tasks of public policy is to ensure stable international relations with other countries in the field of economy and to establish itself as a stable, developed state.

Conclusions. Assessment of modern nature management in Ukraine indicates that in economy uses different types of economic mechanisms for the use of natural resources with different degrees of their development, but it is advisable to develop an economic mechanism for the use of natural resources by agricultural enterprises. The components of its existing elements need to be improved: taxation, insurance, investment in innovative technologies for the use of natural resources and others.

Ecological requirements for nature management, environmental protection and ensuring the environmental safety of society must be performed regardless of ownership, departmental subordination and financial capabilities of economic entities. For this it is necessary to ensure the efficiency and effectiveness of economic regulators of rational and sustainable nature management at the state level.

Improving and implementing the mechanism of economic regulation of environmental activities, taking into account the sectoral characteristics of enterprises, will provide a path to a sustainable type of economic development.

\section{References:}

1. Dubas R.H. (2007) Ekonomika pryrodokorystuvannia [Environmental economics]. Kyiv: MP Lesya. (in Ukrainian)

2. Novakovsky L.Ya. (2007) Sotsialno-ekonomichni problemy suchasnoho zemlekorystuvannia [Socio-economic problems of modern land use]. Kyiv: Harvest. (in Ukrainian)

3. Donnik T.S. (2004) Ekonomichnyi mekhanizm stymuliuvannia v systemi ratsionalnoho vykorystannia pryrodnykh resursiv [Economic mechanism of stimulation in the system of rational natural resources use]. Bulletin of Sumy State University, no. 3-4, pp. 40-42. (in Ukrainian)

4. Melnyk L.H., Shapochka M.K. (2006) Osnovy ekolohii. Ekolohichna ekonomika ta upravlinnia pryrodokorystuvanniam [Principles of Ecology. Ecological economics and nature management]. Sumy: University Book. (in Ukrainian)

5. Tarkhov P.V. (Ed.) (2005) Kryteryy hosudarstvennoho rehulyrovanyia эkonomyky [Criteria for state regulation of economy]. Sumy: GDP of «Dream-1». (in Ukrainian)

6. Golyan V.A. (2007) Ekonomichnyi mekhanizm pryrodokorystuvannia [Economic mechanism of nature management]. Agrosvit, no. 8, pp. 5-12. (in Ukrainian)

7. Bobylev S.N., Khodzhaev A.Sh. (2004) Ekonomika prirodopol'zovaniya [Economics of nature management]. Moscow: INFA-M. (in Russian)

8. Ulyanchenko O.V. (2009). Resursnyi potentsial ahrarnoho sektora ekonomiky Ukrainy: upravlinskyi aspekt [Resource Potential of the Agrarian Sector of Ukrainian Economy: Management Aspect]. Sumy: Environment. (in Ukrainian)

\section{Список використаних джерел:}

1. Дубас Р.Г. Економіка природокористування. Київ : «МП Леся», 2007. 448 с.

2. Новаковський Л.Я. Соціально-економічні проблеми сучасного землекористуванн. Київ : Урожай, 2007.276 с.

3. Доннік Т.С. Економічний механізм стимулювання в системі раціонального використання природних ресурсів. Вісник СДАУ. Сер. Економіка і менеджмент. 2004. Вип. 3-4. С. 40-42. 
4. Мельник Л.Г. Основи екології. Екологічна економіка та управління природокористуванням : підручник. Суми : ВТД «Університетська книга», 2006. 759 с.

5. Тархов П.В. Критерии государственного регулирования экономики : монография. Сумы : ВВП «Мрія-1», 2005. $268 \mathrm{c}$

6. Голян В.А. Економічний механізм природокористування. Агросвіт. 2007. № 8. С. 5-12.

7. Бобылев С.Н., Ходжаев А.Ш. Экономика природопользования : учебник Москва : ИНФА-М, 2004. 501с.

8. Ульянченко О.В. Ресурсний потенціал аграрного сектора економіки України: управлінський аспект. Суми : Довкілля, 2009. 383 с.

E-mail: viktoriyatk@gmail.com 